\section{Carl Nielsen udgaven søsat}

Af førstebibliotekar Niels Krabbe

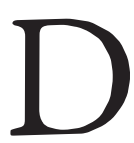

en 9. juni - på komponistens

fødselsdag - udkom de to første bind af den samlede udgave af Carl Nielsens værker, nemlig Symfoni $n r$. 2, udgivet af Niels Bo Foltmann og Symfoni nr. 5, udgivet af Michael Fjeldsøe. Edition Wilhelm Hansen og Det Kongelige Bibliotek var i den anledning værter ved en reception på Det Kongelige Danske Musikkonservatorium, hvor de to bind blev præsenteret for Kulturministeren, repræsentanter for fondsgivere, pressen, musiklivet og Det Kongelige Bibliotek, samt andre indbudte gæster. Zapolsky kvartetten markerede begivenheden med en fremførelse af første og sidste sats af strygekvartetten i F-dur op. 44.

Carl Nielsen Udgaven, der er et særligt projekt under Musikafdelingen på Det Kongelige Bibliotek, blev iværksat i 1994 på daværende Kulturminister Jytte Hildens foranledning. Den direkte anledning var en konstatering af et noget mangelfuldt nodemateriale i forbindelse med en opførelse af Maskarade i Innsbruck. Redaktionsarbejde og produktion finansieres af midler fra Kulturministeriet, suppleret med midler fra en række lang række private fonde. Udgaven er planlagt til at omfatte ialt 32 bind og ventes afsluttet $\mathrm{i}$ løbet af de kommende 10 år.

En samlet, praktisk-videnskabelig udgave af vores Carl Nielsens produktion har været et længe næret ønske blandt musikere og musikforskere, både herhjemme og i udlandet. Dette hænger sammen med en række forhold omkring Carl Nielsens arbejdsmåde og Carl Nielsen-overleveringen i det hele taget. Selv var Carl Nielsen undertiden noget skødesløs, når det gjaldt nøjagtighed og korrekturlæsning, ligesom han gerne overlod til venner og kolleger at rette detaljer i musikken til, sådan som de mente det var bedst. Hertil kommer, at en række værker aldrig har været trykt men kun cirkuleret $\mathrm{i}$ håndskrevne kopier, mens en del af de trykte værker bl.a. af de nævnte grunde foreligger i en ikke ganske pålidelig nodetekst. Endelig skal det anføres, at kildematerialet fra Carl Nielsens hånd i sig selv ofte er ganske kompliceret, og at der forud for fastlæggelsen af det enkelte værks "endegyldige" version kan pågå et betydeligt udredningsarbejde.

Alle disse forhold bidrager til at gøre en samlet udgave af Carl Nielsens værker til et ambitiøst og tidskrævende projekt, og det er udtryk for et kulturpolitisk format, at den økonomiske basis, for at projektet har kunnet realiseres, er blevet skabt.

Hertil kommer, at det i det hele taget må være en selvfølge, at en stor, national komponists samlede produktion foreligger i en kildekritisk udgave mere end 50 år efter komponistens død. Således har det været med de fleste andre såkaldt "store" komponister, og således bør det naturligvis også være med Carl Nielsen. Det startede i midten af forrige århundreder med de store monumentudgaver af Bachs, Händels, Mo- 


\section{MASKARADE}

Ouverture

\section{MASQUERADE}

Overture

Allegro, ma non tanto (d. $=96-100$ )

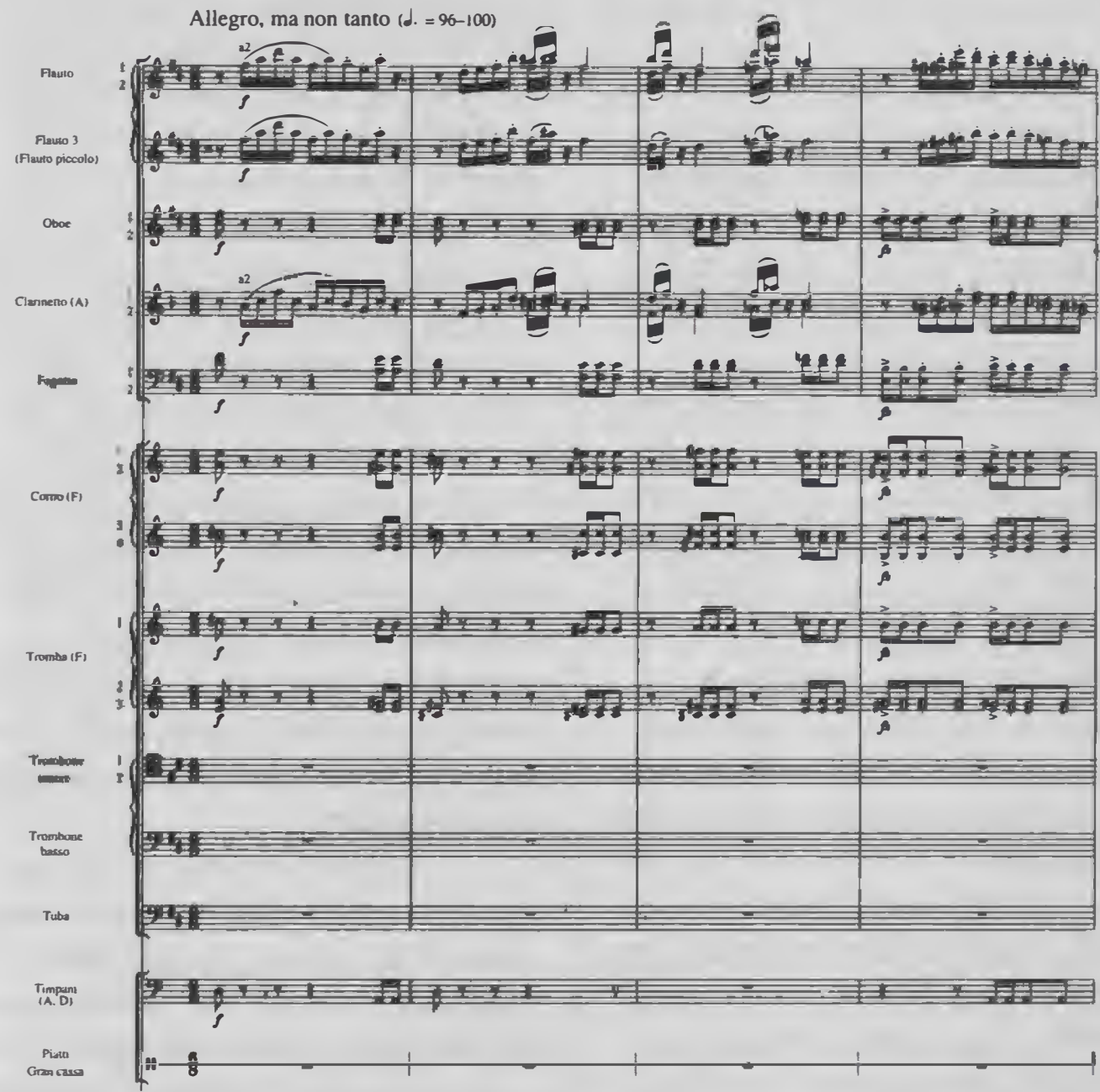

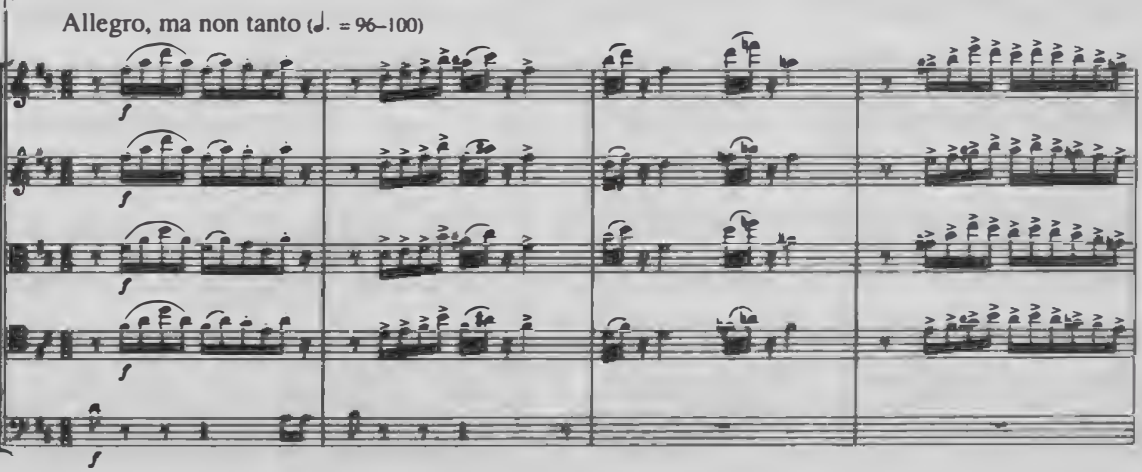

Maskarade, ouverture, side I, CNU-tryk 
zarts og Beethovens værker, og det er siden blev fulgt op med en række kritiskvidenskabelige udgaver af langt den overvejende del musikhistoriens betydelige komponister. Mens man i tidligere tider lagde hovedvægten på den videnskabelige brug af sådanne udgaver, har man i nyere tid sigtet på såvel musikforskningen som det praktiske musikliv. Ligeså selvfølgeligt det er, at musikforskeren må have en pålidelig nodetekst foran sig, når kronologi, stiludvikling, musikanalyse etc. er til behandling, lige så selvfølgeligt er det, at musikerne må vide, præcist hvad komponisten skrev, og - hvor det er relevant - hvorfor der kan være tvivl om, hvad han skrev. For begge målgrupper må udgaven i mindste detalje gøre rede for kilde- og variantforhold samt placere det pågældende værk i sin rette sammenhæng.

Disse krav forsøger den nye udgave af Carl Nielsens værker at leve op til, og man har i arbejdet forsøgt at udnytte de erfaringer, der er gjort af andre store, både danske og udenlandske, udgiverprojekter. Alligevel har man i mangt og meget måttet starte fra grunden og selv måttet gøre en række erfaringer, som bundede i mere specifikke forhold omkring netop Carl Nielsen. En sådan kombination af forskning og udgiverarbejde, byggende på originalt kildemateriale, tager sin tid, når det skal gøres ordentligt. Der er næppe mange om overhovedet nogen - af de hidtil kendte samlede udgaver, der fire år efter deres start har kunnet præsentere de to første bind, således som Carl Nielsen Udgaven kunne gøre det med 2. og 5. Symfoni. Hertil kan føjes, at der i 1998 forventes udsendt yderligere to bind (4. Symfoni og et bind med fire mindre orkesterværker), og at der i løbet af 1999 vil udkomme 5-6 bind, heriblandt det største og i kildemæssig henseende formentlig mest komplicerede af samtlige Carl Nielsens værker, nemlig operaen Maskarade.

Meget overordnet kan man sige, at for at en komponist for alvor kan siges at være inde $i$ varmen, skal i hvert fald tre grundlæggende arbejdsredskaber være tilgængelige:

- $\quad$ en samlet praktisk-videnskabelig udgave af musikken en tematisk værkfortegnelse en fyldig udgave af den skriftlige produktion (breve, artikler og andre litterære frembringelser)

Også her kan man konstatere, at således er situationen omkring mange komponister - men endnu ikke Carl Nielsen. De tre kategorier hænger nøje sammen, og hver for sig forudsætter de faktisk hinanden. Det kan således diskuteres, om det er klogt at kaste sig ud i den samlede udgave af værkerne, for hele produktionen er kortlagt i den tematiske værkfortegnelse; omvendt kan man sige, at netop arbejdet med kilderne i forbindelse med den samlede udgave er en nødvendig forudsætning for at kunne foretage registreringen i værkfortegnelsen ... og sådan kunne man blive ved. Ét sted skal man starte, og for Carl Nielsens vedkommende er dette af grunde, der er forsøgt gjort rede for i det foregående, sket med udgaven. Hertil kan så føjes, at det næppe ville være 
unaturligt om Carl Nielsen Udgaven på et tidspunkt også påtog sig arbejdet med de to øvrige kategorier. Faktisk samler man med dette i tankerne konstant materiale til senere benyttelse, og der er allerede gjort visse tanker om en udmøntning i praksis af dette materiale.

Der er således et stykke vej igen, før "udenværkerne" omkring Carl Nielsen er tilfredsstillende og før fundamentet for det kommende årtusinds fornyede beskæftigelse med Carl Nielsens liv og værk er lagt, en beskæftigelse, som bør munde ud $i$ en autoritativ monografi om Carl Nielsens, skrevet på grundlag af det samlede kildemateriale.
$\mathrm{M}$

Men med lanceringen af de to første bind i den samlede udgave er et meget vigtigt første skridt taget, og hele baggrunden for udgavens tilblivelse, dens ressourcemæssige fundering samt det arbejde, der er gjort i de foregående fire år, er udtryk for at vi også her til lands lever op til vores musikkulturelle forpligtelser.

Orientering om udgavens baggrund, bemanding og udgivelsesplan kan læses på følgende web-adresse: http:// www.kb.dk/kb/dept $/ \mathrm{nbo} / \mathrm{ma} / \mathrm{cnu}$.htm 